\title{
Simon Miklós
}

\section{FÜGGŐSÉG - KOMMUNIKÁCIÓ - AUTONÓMIA I.}

\author{
Addikt Állapotoktól az Addiktológia \\ Állapotáig (és vissza) \\ - kommunikatív elemzés -
}

\author{
Hol függőség van, \\ ott függöség van \\ nemcsak a zsigerekben, \\ nemcsak a fejekben...
}

(Illyés parafrázis)

Amikor Gorbacsov megkérdezte a szakembereket, mi lehet az oka az alkoholizmusnak a Szovjetunióban, a szakemberek szinte egyöntetüen állították: az alkohol. Az akkor kiirtott hatalmas szőlöültetvényeknek csupán töredékét sikerült azóta pótolni. A rászorulók (az ezzel és ebböl élők) alternatív megoldások után néztek, az ültetvények helyére parlagfü települt. A politikus egyszerü ember. Nem szereti az ,intellektuális mellébeszélést”. Kérdéseire egyszerü, egyenes választ vár. (Esni fog, vagy nem? Nem érdekli „légköri nyomás”, „felszálló légáramlat”, „anticiklon” „százalékos valószínüség”, stb.) És meg is kapja. A szakember megtanulta a leckét. Aki fizet, az rendeli a zenét. A híradóban még azt is megmondják, vigyünk-e magunkkal esernyőt. Cserébe nem firtatjuk az előző napi előrejelzést. A lényeget úgyis tudjuk: holnap nagyjából ugyanolyan idő lesz, mint ma volt. (Amennyit mégis változik, az hibahatáron belül van.)

A szovjet példából (de sorolhatnám az amerikai prohibíció, majd a „drogháború” alapvetően tanulság nélküli kudarcait, vagy itthonról a drogprevenció gyakorlatának szintén soha le nem vont tanulságait) nem a javaslatok - olykor a józan észnek, közgondolkodásnak is ellentmondó - látványos kudarca a figyelemre méltó. Ilyen, szinte primitívvé egyszerüsített közelítésben ez könnyen előfordul, és nem idegen a politikától sem. A figyelemre méltó az, hogy ezek a balfogások újra, meg újra ismétlödnek. Meg kell vizsgálnunk: mi lehet ennek az oka, milyen úton jutunk mindig ugyanoda? Mi a kommunikatív, ami ezt az állapotot fenntartja? Mi konzerválja, védi akár évtizedekre az addiktológia szignifikátumainak és szignifikánsainak töretlen változatlanságát, s vele a kommunikatív színtér egyéb ágenseivel való diskurzus eleve behatároltságát? Ezzel összefüggésben: az „addikt ügyek” intézésének miféle „technicizációja" tartja fogva az addiktológia és az addiktológiával foglalkozók társadalmi kommunikatív állapotát?

${ }^{1}$ A tanulmány itt olvasható első részében az addiktológia addikt kollektív ágenssé válásának folyamatát vizsgálom (kommunikatív elemzés), míg második - a Jel-Kép 2016/2 számában megjelenő részében a kialakult addikt kommunikatív állapot következményeit és máig ható, torz produktumait teszem vizsgálat tárgyává (szakmai elemzés). Mindkét tárgykörben javaslatot is teszek a helyzet meghaladására. 


\section{Háttér}

Az addiktológia, a szintén nem oly rég önállósult pszichiátria gyámolítottjaként, örökli alig felserdült gyámja összes kiforratlan/megoldatlan, társadalmi színtéren természettudományos (orvosi) szemlélettel csetlő-botló esetlenségét, bizonytalanságát. Merev, oksági szemléletét a fókusz és keretezés szükre szabásával igyekszik fenntartani, a társadalomtudományokban szokásos többszörös meghatározottságok számbavételének esélytelenségével. Nem a kerethez igazítja leírását, hanem diagnózisához rendel igény szerinti kereteket. Kompetenciáit így rendre túllépve, számtalan esetben bizonyul „túl nagynak a kabát”. ${ }^{2}$ Miközben azonban, a pszichiátria lassan mégis meghaladni látszik neurológiai eredetét, az addiktológia toxikológiai szemlélete máig meghatározó. ${ }^{3}$

\section{Kérdés, kérdés hátán}

Sokan foglalkoznak ma addiktológiával, azt mégsem tudjuk, mivel foglalkozik az addiktológia? (A toxikológus mérgekkel és azok ellenszereivel foglalkozik. Pszichológusok, ha addikt jelenségek mechanizmusait, szociológusok, ha kiterjedtségét vizsgálják, nem lépnek túl szaktudományuk - pszichológia, szociológia - határain.) De végül is ki addiktológus, és mivel foglalkozik az addiktológia? Van-e például tárgya, speciális eszköztára? Van-e közmegegyezéses jelenségköre? Vannak-e szaktudományos ismérvei, megállapított törvényszerüségei? Ezeknek kritériumai, kategóriái, mértéke, változói? Vannak-e irányzatai, adekvát kérdései, ezekre adott válaszai? Van-e közös szakmai nyelve, általános jelenségeit leíró terminológiája, melyen a téma szakemberei szakmai diskurzust folytatva építkeznének?

A kérdéssor megválaszolásához további, praktikusan egyszerü kérdések átgondolására van szükség: Ellátja-e elvárt feladatát (egyéni-, társas-, társadalmi szinten)? Vagyis: a.) képes-e a bajbajutottakon hatékonyan segíteni? b.) képes-e szakpolitikai döntésekhez megbízható, az idő próbáját is kiálló háttéranyagot szolgáltatni? Képes-e a mindenkori drogpolitikát hatékonyságával, koherens szakmai érvrendszerével befolyásolni? Beletörödik-e alárendelt, „egyetértési joggal felruházott" szerepébe? Esetleg független szakmaiságát feladva, s a politika mezejére lépve, netán önmaga kíván alternatív drogpolitikává válni? Rendelkezik-e szakmai és/vagy politikai minőségében a tőle elvárt, neki tulajdonított, a társadalmi folyamatokat értő, az iskolai nevelést, az egyéni sorsokat befolyásoló kompetenciákkal ill. (utóbbi esetben) legitimációval?

A jelenlegi öszvér-állapot az addiktológia és az addiktológusnak nevezett szakember helyét kereső, bizonytalan identitásából következik. (Ez ugyan világjelenség, ám ettől eltérő, egyedi utak is szép számmal akadnak.) Ez a köztes állapot lehetővé teszi, hogy ha politikusként menesztik, szakmaiságát sirassa, ha szakemberként kérdezik, sértett politikusként reagáljon. Egyéni stratégiaként érthető, szakmai szempontból zsákutca. Sok múlik azon, hogy az addiktológia az elkövetkezö években képes lesz-e megteremteni hiteles szakmai identitását, vagy a mindenkori politika függvényeként, annak kiszolgálójaként/ zsarolójaként (Tapolyai 2002) próbál-e a továbbiakban is érvényesülni?

2 Ezért is van szűnni nem akaró problémája a „norma”, „,deviancia” „,betegség/egészség” témakörével. (Pethő 2008), (Gyetvai 2010), (Rácz 2011), (Buda 2012)

${ }^{3}$ Ezért beszél szívesebben az addiktológia okságinak tünő „,boldogság-hormonról”, vagy ,,adrenalinfüggésröl” az érthetőbb és természetesebb „örömháztartás” vagy „,kontrollfüggő attitüd” más nézöpontú, viselkedés szintü (leíró) megközelítése helyett. 


\section{Kettös aspektus}

A probléma egyrészt az addiktológia általános, diszciplínán belüli, szakmai koherenciával (szignifikációival) kapcsolatos problémájaként, másrészt az addiktológia változó környezetével, (társadalmi/politikai) beágyazottságával - a speciális magyar viszonyokkal kapcsolatos (kommunikatív) problémájaként rekonstruálható. Az első kérdés tehát az addiktológia egészére vonatkozik és szignifikatív elemzést igényel, a másodikban a magyarországi speciális viszonyoknak van döntő jelentősége, ezért ez esetben kommunikatív elemzés lehet célravezető. Ezek vizsgálatához ezúttal is Horányi Özséb társadalmi részvételre épülő (Horányi 2009/b) kommunikáció-elméletét (PTC) és kommunikatív eszközrendszerét veszem igénybe, ahogyan azt már korábbi tanulmányomban - az addikt jelenségek rekonstrukciós elemzését javasolva - is tettem. (Simon 2014)

\section{Kommunikatív elemzés}

\section{Színtér}

A gyorsan változó hazai sajátosságokra tekintettel egyszerre vizsgálnunk kell a fennálló kommunikatív állapot előzményeit, hatásait és esetleges meghaladásának lehetőségeit. A ,drogszcéna" ágenseinek szignifikációi és kommunikatív állapota a hatalomhoz, a politikához (,,drogpolitikához”), illetve a szakmájukhoz való közelségük alapján rekonstruálható. Adott társadalmi kommunikatív térben e koordináták mentén helyzetük, mozgásuk, helyezkedésük időről-időre jól követhető.

A színtér megválasztása tehát társadalmi léptékü, ágensei a „,drogszcéna "4 szereplői, kitüntetetten annak hatalomban lévő ágense (,drogpolitikus”) és a hatalmi disztribúción jelenleg kívül lévő, magát (korábbi hatalom-közelibb pozíciójához képest) „kisemmizettnek” érző, előbbiek által ,,droglobbinak” nevezett kollektív ágens érdekcsoportja. Nem nehéz belátni, ahogy „fogyasztó” és „ellátó” egyéni ágensek, úgy a „droglobbi” és a „drogpolitikus” is ugyanazon, „drogszcéna” részvevői, egymást feltételező, kiegészítő (kollektív) ágensek. Létük szimbiotikus párjuk létének függvénye. Ez a közelmúltbéli állapot. Tanulmányomban elöször az általános (addiktológiai) szignifikáció alapállapotát tekintem át, majd a közelmúltbéli kommunikatív állapot elözményeit és máig tartó következményeit vizsgálom nevezett kollektív ágensek időben egymást követő kommunikatív állapotainak ,„pillanatfelvételein”. 5

\section{Szignifikativ}

Nézzük tehát - viszonylagosan rendszerbe szedve, és amennyire lehet, tömörré csupaszítva az addiktológia hibásnak, gyengének vagy gyanúsnak tetsző felépítése belső logikájában azokat az ellentmondásokat, részigazságokat, melyek kapcsán évek óta folyamatosan külső és belső bírálatok érik, de amelyekkel évek óta - úgy tünik - mégis gond nélkül, „vidáman”

4 A „drogszcéna” kifejezést 2011-ben tartott első, nagyszabású tiltakozó összejövetelükön önmagukra alkalmazták a szakma részvevői annak kapcsán, hogy az új politikai hatalom a korábbi évekhez képest drasztikusan csökkentette a területnek juttatott pénzeket. Ebben a tanulmányban szerző a kifejezést teljesebb körben, a hatalmat képviselő szakpolitikusokat is beleértve használja, annál is inkább, mert ebböl a perspektívából (szaktudományos nézőpontból) álláspontjaik között lényegi eltérés alig mutatkozik.

5 „Hatalmi” és „drogpolitikai” szempontú szignifikatív áttekintésére nem vállalkozom. Ez utóbbi tárgyban leginkább magukat a „Tervezeteket”, illetve Sárosi Péter (2011) áttekintő („drogpolitikai”) tanulmányát ajánlom. 
együtt él. ${ }^{6}$ Egyszerü szempontrendszert javaslok: vizsgáljuk úgy, mintha tudomány lenne, félretéve egyelőre azt a megalapozottnak tünő gyanúnkat, hogy (nézőpontunkból) szedettvedettnek tünő felépítését alapvetően más szempontok vezérlik.

\section{a.) Tisztázatlan, pontatlan, vagy hiányzó terminológia}

- Definiálatlan fogalmakkal (,,drog”), (,,kapu”), (,,drogos”) operál, a leírások többsége ebből következően annyira általános, hogy - ebben a formában - inkább közhelyszerü, mintsem valódi, társadalmilag, egyénileg hasznosítható információ forrása. ${ }^{7}$

- Még az olyan fogalmak, mint „substance” vagy „,dependence” is, meglehetősen kevés támpontot nyújtanak a rendellenesség súlyosságára, vagy a kezelés mibenlétére vonatkozóan. Ezek további összevonása „substance use disorder” közös fogalommá (DSM-5-ben) a diagnosztikus kategórián belüli lehetséges változatok további növelését eredményezi. (Brink Scippers 2012)

- Ideológiailag szennyezett fogalmaiban ideológiai (politikai) vagy morális jobbító szándék és kutatás kontrollálatlanul mosódik egybe.

- A konkrét esetleírás szintjéröl valamiféle általánosabb érvényü megállapítás szintjére lépés érdekében hibás út az addikt-tárgyak összemosása végső esetben valami féle Jolly-joker „drog” fogalommá. (Helyette sokkal inkább az addikt jelenségek szimptomatikus etapjainak egybevetése /metszete és folyamata/ hozhat értékelhető eredményt). (Simon 2012, 2014)

\section{b.) Hibás, előítéletes professzionális attitűd}

- Társadalmi szinten a „mi normálisok” intoleráns elhatárolódásban a média, gerjesztő szerepét említik sokan. (Young 1974) Jellemzőbbnek tartom ennél a függőség, mint „betegség” felfogásából ${ }^{8}$ adódó össztársadalmi tagadás („,denial”) törvényszerü reakcióját, amelyet a tisztázatlan „drog” fogalom nyelvi szinten is megalapoz (kifejez). (Simon 2005, 2012)

- Sokan állítják (szemben az alkoholizmust betegségként számon tartó irányzatokkal), hogy olyan címkék, mint ,alkoholista” vagy „függő” éppen hogy kontra-produktívak, több kárt, mint hasznot hoznak (Fingarette 1990); ennek elfogadása Wesson, Havassy \& Smith (1986) szerint erősen kapcsolatba hozható a függőség élethosszig tartó, gyógyíthatatlan betegségként való elkönyvelésével. (Chiauzzi - Liljegren 1993)

${ }^{6}$ Egyetlen tudomány sem létezhet huzamosabb ideig a következetes gondolkodás szabályait ennyiféleképpen és ilyen mértékben figyelmen kívül hagyó belső ellentmondások feszítésében. (Egyik sem kap ugyanakkor ekkora lehetőséget társadalmi folyamatoknak az „elgondolásai” szerint történő - ellensúly, vagy alternatívák nélküli - szabad befolyásolására.) Egyebek mellett ez is indokolja a problémák számbavételét.

${ }^{7}$ Máig emlékezetes számomra az a valóban kínos jelenet, mely a még müködő Nap-TV Kinn-padon rovata szenzációsnak szánt vitamüsorában hangzott el évekkel ezelőtt. Meghívták erre a Kendermag Egyesület vezetőjét és vitapartneréül egy idősebb urat a „drog” elleni küzdelem élharcosaként. Hosszú percek óta ment az egyre élesebb hangú müsor, amikor az idős úr nem bírta tovább a fiatalabb „flegmaságát” és felcsattant: „Maga legalizálni akarja, amitől az én fiam az életét vesztette!” Mire a másik meglepetten: „De hát tudomásom szerint még senki nem halt meg marihuána túladagolásától!” „Ki beszél itt marihuánáról? Az én fiam heroin túladagolása miatt vesztette az életét!” „Sajnos a müsoridőnk lejárt, legközelebb innen folytatjuk” - közli a szerkesztő. Ám a fiktív drogfogalom továbbra is kábít bennünket.

${ }^{8}$ Betegségből indul ki, pedig ez olyan, mintha az emberi elme konstruktivitását a paranoia felől próbálnánk megérteni. 
- Diagnosztikus kategóriái felállításakor életkori sajátosságokat, súlyossági, veszélyeztetettségi (pláne egyedi!) különbségeket alig vesz figyelembe, holott ezek legtöbb esetben jóval döntőbbnek bizonyulnak, mint magának az addikt-tárgynak a sajátosságai. Az addikt állapotot statikusként („drogos”), nem annak dinamikus folyamatában kezeli. (Chiauzzi - Liljegren, S. 1993)

- Ha mégis, a „bünös tevékenység” elvére épülő felfogások (lásd: „kapudrog” vagy „,drogkarrier” fogalmai) egyirányúnak tételezik a folyamatot, ami súlyosan stigmatizál. Ez a visszaút esélyeit lebecsüli, azt kivételes lehetőségnek tartja. (Vö. pl. a „bukott angyal” szindróma, vagy ,,jojó effektus" és hasonló köznapi jelenségek iatrogén ártalomként való létrejöttét a helytelen összefüggésbe helyezett, elmarasztaló értékelés lehetséges következményeként.)

- Adódik ez főként abból, hogy az addiktológia fóárama a megbetegedés tényének megállapítását, pontos „diagnosztizálását” (sic!), olykor folyamatának nyomon követését még tárgyának tekinti, a szabadulás (gyógyulás) spontán folyamatait azonban - úgy tünik - már nem tartja annak. ${ }^{9}$ Ez a felemás attitűd bizonyos jelenségeket (denial, relapszusok) inkább tart a „,betegség sajátossága" visszahúzó (negatív), mintsem a kliens „egészséghez való ragaszkodása”, vagy „,változtatni kívánó tapasztalatgyüjtése” (Prochaska et al. 1992, 2009) elöre tekintö (pozitív) tüneteinek.

- Éles elhatárolódást tesz a „drogosok” és a „mi” között, mégis adós annak a gyakorlati (pl. szülői, pedagógusi) szempontból igen lényegesnek tünő szempontrendszernek a megteremtésével, mely egy addikt kontinuum mentén - legalább hozzávetőlegesen - meghatározná, hol van olyan „kritikus pont”, ahol veszélyeztetettség figyelmeztet, vagy ahonnan a visszafordulás vagy újrakezdés egyre nagyobb valószínüséggel külső segítséget igényel. ${ }^{10}$

\section{c.) Hibás logikájú, vagy téves megközelítések, ebből eredő hibás döntések, döntés-előkészítések}

- A diszciplína szignifikátuma nem valamely pszichoaktív hatóanyag, azt egy másik igen tiszteletre méltó tudomány (toxikológia) vizsgálja, hanem a függőség egyéni, társas, társadalmi szintü jelenségei, és ezek szinergiái. Felfogásom szerint ez a korszerü kommunikáció-tudomány keretei közt lehetséges. Az addikt-tárgy vizsgálatának ebben az összefüggésben lehet szerepe.

- Egy alapvetően társadalmi jelenséghez az élettudományok magyarázni kívánó szemléletével közelít. A társadalomtudományok megérteni, a természettudományok inkább magyarázni törekszenek vizsgálatuk tárgyát. Ebből aztán nagyon egyszerű képletek születnek. (emlékeznek bizonyára: ,az alkoholizmus oka az alkohol”). Az egyvágányú diszpozicionális magyarázatoknak a megvilágító ereje nem túl nagy, de előnyük, hogy szinte lehetetlenné teszik további magyarázat kérését. (Pete 2006)

- A ma legnagyobb hatású felfogás az időbeni egymásutániságot ok-okozati kapcsolatnak tételezi. Az alap-elmélet az általa létrehozott kategóriával ,igazolja" a létrehozó elvet (petitio principii). (Kandel - Yamaguchi 1993, Vanyukov et al. 2012)

- A meghatározatlan nézőpontból készült leírásokkal kapcsolatosan óhatatlanul felmerül a „megfigyelö és cselekvő perceptuális torzításából” adódó attribúciós hiba (Rácz 2002) lehetősége.

- A diszciplína tárgyának tisztázatlansága, a kontroll helye (Rotter 1966) konkrét helyzetben történő pontatlan meghatározásával („lebegtetésével”) a felelősség külső ágensre történő áthárításának kézenfekvő lehetőségét nyújtja. Ezt a gondolatot bővebben kifejti több új kiadást is megélt könyvében John D. Booth. (Booth 1992)

${ }^{9}$ Mintha az onkológust csak a betegség progressziója érdekelné, a gyógyulás folyamatai, feltételei már nem.

${ }^{10}$ Ezen a téren „pedagógiai” (és „prevenciós”) céllal a „zéró tolerancia” nehezen értelmezhető, farizeus álláspontja vált leginkább elterjedté. 
- A reprezentativitás, ill. az egyediség problémája. Általános tapasztalatok érvényesítése az egyedi esetek sajátosságainak tiszteletben tartása nélkül, illetve beteg-populáció klinikai (egyedi) tapasztalatai alapján esetenként nekibuzduló országos ,prevenció” szervezése - ekkora variabilitás esetén kódolhatóan kudarcra ítélt, nem mellesleg komoly (szakmai, erkölcsi) károkkal járó, felelőtlen vállalkozások.

\section{Kommunikatív}

\section{(ill. az addikt kommunikatív folyamat-elemzés három stádiuma (Funk 2000))}

A rendszerváltással megnőtt lehetőségekkel, a fogyasztási szokások, s a korábbi kínálathoz kialakult szabályozó és kontroll mechanizmusok felkészületlennek, elégtelennek, eszköztelennek bizonyultak. Ez az eszköztelenség széles társadalmi rétegek kiszolgáltatottá, védtelenné válását eredményezte. Itt a kamasz gyerek éppúgy veszélyeztetetté vált a veszélyes és csábítóan kínált új élményekkel szemben, mint a nyugdíjas az élethosszabbító orvosi eszközöket százezrekért nyakába sózó, kifinomult marketing-technikákkal szemben. De (értelmezésünkben) addikt veszélyeztetetté váltak politikusok, szakpolitikusok, sőt egész szakmák is, amennyiben kevéssé védte őket évek során csiszolódó integritásuk.

A (szintén nem oly régen önállósult) pszichiátria alkohológiával, toxikológiával foglalkozó szakemberei a legnagyobb természetességgel fordultak az új kihívások felé. Orvosi szemléletük, kóroktani gondolkodásuk azonban minden addikt jelenség mögött törvényszerüen „hatóanyagot”, kemikáliát keresett. A politikának pedig az a sajátja, hogy szinte állandósult tünetként egyszerüen megfogalmazható, látványos közellenségre van szüksége. Feltörekvő politika és feltörekvő addiktológia e területen egymásra talált. Közös termékük ,a drog” nevü média-fikció, melyből a politika rendszeresen és ,jó adagot” irat magának. (Igaz, jól meg is fizeti). („Mézeshetek”, 1. stádium” mondaná Funk dr., lásd Funk 2000.)

Az addiktológia pedig adja, sőt megnövekedett hatalmára ébredve, egyre többet és egyre nagyobb adagokban. ${ }^{11}$ Olykor már kéretlenül is. (A tolerancia nő, a drive szintén.) ,A droghelyzet fokozódik'(!), ${ }^{12}$ hallhatjuk nap-mint nap, s a foglyul ejtett állam fizet. Egy ,valódi” és egy „csinált” probléma e ponton egyre élesebben válik ketté. (Az elöbbi a rendszerváltást követő fentebb leírt társadalmi veszélyeztetettség valós, napi kihívásait, utóbbi a morális pánikkeltés érdekében fiktív „drogmumus” kergetését, sajátos „látványkommunikáció” művelését, egyúttal a sóvárgó politika napi ellátását jelenti. (2. stádium)

Az állam azonban (a soros kormányváltást kihasználva) megragadja az alkalmat, és keményen „visszazsarol”. Korábbi juttatásait 1/10-ére csökkenti. A „drogszcéna” komoly sérelmet szenvedett szakmai csoportja évek óta szervezetten és eröteljesen tiltakozik, tizedére csökkentett ellátottságát, korábbi privilegizált helyzetét visszasírva/követelve, jól szervezett, közös kisemmizett érdekcsoportot alkotva, ám meggyőző társadalmi hasznosságot felmutatni képes szakmai érvrendszer nélkül. Nyilvánvalónak látszik, hogy ezen a terepen (a politikai

${ }^{11}$ A híranyagokban rendszeresen jelenik meg ekkor a nem túl fantáziadúsan variált „,kaptafa-mondat: „A budapesti (magyarországi) középiskolákban (szakiskolákban, szakközépiskolákban) minden második (harmadik, ötödik) fiatal kipróbálta (találkozott, megkóstolta) már a drogot." Definiálatlan fogalmak, elsikkadó reprezentativitás, ismeretlen módszertan. Igazi „brit kutatók felmérése szerint” típusú, de kiszámíthatóan célzott hatású, hangulatkeltő híranyag. (Simon 2005)

${ }^{12}$ Szerző ezekben a kritikus években, félállású iskolapszichológusként, egy fővárosi építőipari szakiskola pszichológiai feladatait látta el. Ez idő alatt, néhány banális eseten kívül, nem találkozott komolyabb visszaéléssel. Egyik esetben viszont két éves munkájába telt, hogy az „elterelés” következtében jelentősen megnőtt veszélyeztetettséget, segítő háttér-tevékenységével megfelelően kompenzálja. 
arrogancia mezején) nála jobban pozícionált, felkészültebb ellenfelek játszanak. Tiltakozása így lepereg, egyéb (szakmai) fegyvere csorba. Ez idegen pálya. Erről a pályáról mielöbb célszerü levonulni. (3. stádium)

\section{1. táblázat}

Az addiktológia ,,addikt kollektív ágenssé” válásának folyamata (a lehetséges változások szakaszaival)

\begin{tabular}{|c|c|c|}
\hline \multicolumn{3}{|c|}{ Társadalmi szintü addikt kommunikatív állapotok $(1,2,3)$ progrediálásának folyamata } \\
\hline 1. stádium & $\begin{array}{l}\text { - Az addiktológia nevében hozott döntések, valójában } \\
\text { politikai döntések, az addiktológiát a politika döntései } \\
\text { legitimálására használja. } \\
\text { - Az alárendelt, kitartott szerep } \rightarrow \text { a formálódó szakmát } \\
\text { nem elégíti ki. }\end{array}$ & politikai visszaélés \\
\hline 2. stádium & $\begin{array}{l}\text { - Pygmalion életre kel, és önálló tevékenységbe kezd. } \\
\text { - Mesterséges igényt kelt önmaga iránt, megszervezi } \\
\text { az állami juttatások elosztását (technicizálás) } \rightarrow \text { önjá- } \\
\text { róvá válik, átveszi a raportot. } \\
\text { - Ennek fenntartása érdekében szakmai kompetenciái } \\
\text { helyett célszerüen a zsaroló potenciálját fejleszti (techn- } \\
\text { icizálás kiteljesítése, másodszándékú kommunikáció, } \\
\text { morális pánikkeltés). }\end{array}$ & $\begin{array}{l}\text { szervezeti } \\
\text { visszaélés, } \\
\text {,state capture"13 } \\
\text { (Martini 2014) }\end{array}$ \\
\hline 3. stádium & $\begin{array}{l}\text { - A „birodalom visszavág”, kodependencia, kölcsönös } \\
\text { függőség } \rightarrow \text { „róka fogta csuka”. } \\
\text { - Kommunikatív „,pattállapot”. } \\
\text { - Erős „,megvonásos tünetek”, denial. } \\
\text { - Mindenki rosszul jár (szakmai, kapcsolati, társadalmi } \\
\text { leépülés). Hosszú távon fenntarthatatlan addikt kommu- } \\
\text { nikatív állapot. }\end{array}$ & $\begin{array}{l}\text { kölcsönös } \\
\text { visszaélés } \\
\text { (jelen állapot) }\end{array}$ \\
\hline VAGY: & \multicolumn{2}{|c|}{ A szabadulás ciklikus szakaszai (Prochaska et al.) } \\
\hline & $\begin{array}{l}\text { a.) Nincs szándék a viselkedés változtatására. } \\
\text { b.) A probléma felismerése cselekvési szándék nélkül. } \\
\text { c.) Szándék a probléma megoldására. } \\
\text { d.) Aktív viselkedésváltoztatás. } \\
\text { e.) Kitartó változás, új viselkedés megjelenése. } \\
\text { f.) Visszaesés korábbi viselkedésmintákba. } \\
\text { (Lásd 1. ábra) }\end{array}$ & $\begin{array}{l}\text { Pre-contemplation } \\
\text { Contemplation } \\
\text { Preparation } \\
\text { Action } \\
\text { Maintenance } \\
\text { Relapse }\end{array}$ \\
\hline
\end{tabular}

${ }^{13}$ Transparency International (2009) The Anti-Corruption Plain Language Guide. http://www.transparency.org/whatwedo/publication/the anti corruption plain language guide 


\section{1. ábra}

A szabadulás ciklikus szakaszai (Prochaska et al 1992, 2009, Simon 2014)

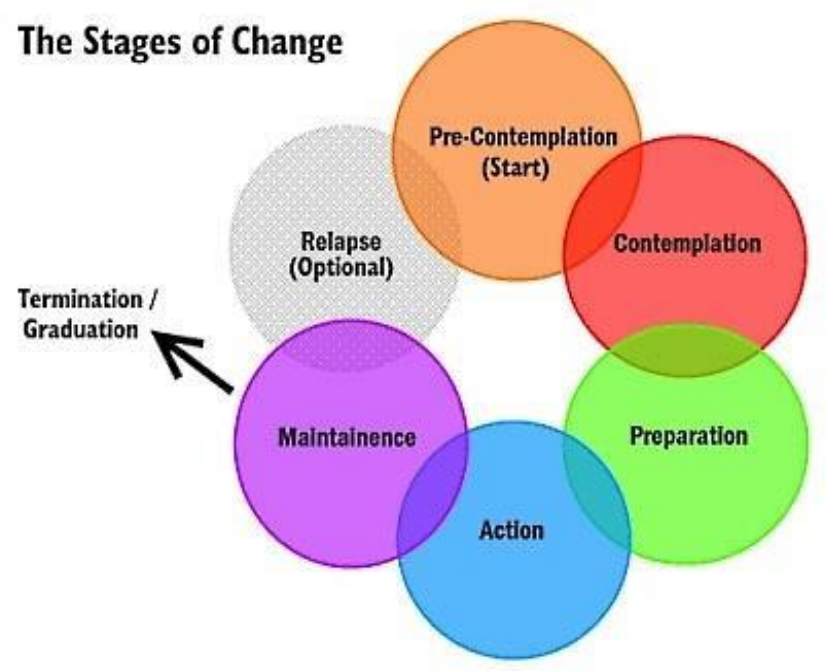

forrás: http://www.smartrecovery.org/resources/library/Articles_and_Essays/Stages_of_Changel understanding_stages_of_change.htm (James Prochaska)

\section{Feltételrendszer és müködtetö mechanizmusok}

A vizsgált szintér jelentős ágense (róla eddig kevés szó esett) a „drogfogalom” fogyasztója, akinek reakciójára számítva „drogmumus” maga is életre kelt. Most azért citálom, mert a bevezetőben feltett „miért” és „hogyan” kérdések megválaszolásához a deviancia és a média szociológiai irodalmából eredeztetett morális pánik (Kitzinger 2000) fogalmához kell visszanyúlnunk. A Császi által (McRobbie 1994, ill. McRobbie és Thonton 1995 nyomán) említett „régi” és „új” típusokhoz képest (Császi 2003) az itt felismert legújabb típus tulajdonképpen egy harmadik forma. Idöközben a szakmai médiaismeret igen magas fokúvá vált, ehhez képest a média-fogyasztás még mindig kissé naiv, kezdetleges. Ebböl következően a médiahatás professzionális kezekben sok esetben olyannyira kiszámítható, hogy nagy biztonsággal lehet számolni az általa kiváltott, kalkulált társadalmi reakcióval. ${ }^{14}$ Így tehát - a vizsgált esetben is kevésbé morális pánikról, még kevésbé új típusú társadalmi „,rítusról”, sokkal inkább profeszszionális tudatossággal alkalmazott (egyoldalú) morális pánikkeltésröl beszélhetünk. Arról, hogy a morális pánikkeltés voltaképpen a technicizálás (Jancsics - Jávor 2012, Jávor 2014) részeként illeszkedik az érdekszféra szervezeti eszköztárába. A kulcspozícióin keresztül hatáskörbe vont érdekközösség (jó ,felelötlen szervezetként”) ez utóbbi lépéssel, az immár kalkulált és manipulált médiahatás révén, a bekövetkező társadalmi fogadtatásnak is (kiszámíthatóan és kockázatmentesen) megágyaz. A szervezeti viselkedés jellemzőjeként annak egyes tagjai - többnyire spontán és jó szándékkal - a szervezet részeiként szolgálják annak ki nem mondott, látens céljait. Információ hiányában csupán kevés magas pozíciót betöltő vezető láthatja csak át a szervezeti müködés egészének a deklarálttól eltérö, valós céljait.

\footnotetext{
${ }^{14}$ Ezúton válhat sok más esetben is ,politikacsinálás” részévé.
} 


\section{Addikt kollektív ágencia}

Külső szemlélő számára a történet pikantériáját talán leginkább az addiktológia addikt kollektív ágenssé válásának folyamata adhatja, amiben azonban semmi meglepő nincs. Sőt, a társadalmi kommunikatív állapot adott viszonyait tekintve csaknem törvényszerünek mondható. Ha a szervezeti és a társadalmi környezeti feltételek ${ }^{15}$ adottak - márpedig, a rendszerváltás következtében Magyarországon különösen azok - a rövidtávú érdekek mentén szerveződő addikt kötődés meg tud történni. És ami megtörténhet, az meg is történik, függetlenül valamely érdekcsoport eredeti céljaitól, és tevékenységének eredeti tárgyától. Megfelelő feltételek esetén igazi, sodró addikt folyamat áll elő, melynek újabb és újabb kommunikatív színterein ágens egyre újabb döntési helyzetekbe kerül, újabb problémákat kell azonosítania és kell rájuk megfelelő választ adnia. Éppen úgy, ahogyan azt a „,Hajnali feles” modellen demonstrált addikt folyamat egyes stádiumainak rekonstruálása során korábbi tanulmányomban bemutattam. (Simon M. Jel-Kép 2014/2)

Ami talán mégis feltünést keltő, az a szakmai érvekkel szembeni makacs változatlanság és stabilitás, ami a kölcsönös függőségben való egymásra talált/utalt felek kiegyensúlyozott erőviszonyaiból és - talán furcsa, de - megelégedettségéből adódik. Megtévesztheti az is a kívülállót, hogy a „drogszcénán” belül, civil szervezetként fellépő szakmai érdekcsoport („droglobbi”) és a „drogpolitika” közt fel-fellobbanó parázs vitákban látszólag „,szakmai ellentét” nyilvánul meg. Félreértés ne essék, itt lényegi szakmai ellentét nincs a felek között. A vita valójában az anyagi és természeti javak (pénz és hatalom) elosztásáról szól, ahogy arra korábban már utaltam. A társadalmi kontroll alól „elszabadult”, egyúttal azonban súlyosan függővé is vált érdekközösség a közvélemény manipulálásán keresztül ugyan foglyul ejti az államot, ám ezzel a lépéssel önmagát is súlyosan kiszolgáltatott, kodependens állapotba hozza. Ráadásul az a látszólagos érdekeltség, amely ennyire zárt közösséggé teszi tagjait, ma alig teszi lehetővé a közösségen belülről jövő szakmai innováció felbukkanását. És valóban, az utóbbi idők addikt témával kapcsolatos újszerü, friss gondolatai - Máté Gábor dr. (2012), Prochaska J. és tsai (1992, 2009), Gerald May (2006), Ann Gadd (2012), H-Peter Röhr (2014), Feldmár András (1997), Tapolyai Mihály (2002), stb. - valamennyien az elemzett „drogszférán” kívülről érkeztek.

A kínálkozó lehetőségek csábereje ${ }^{16}$ (incentív), a belső késztetés ${ }^{17}$ (drive) igénye az adódó lehetőségeket kollektív ágenciák estén is saját (rövid távú) érdekei szerint alakítja. A szervezeti viselkedésnek ezek az újszerü szempontjai olyan vizsgálatokra adnak lehetőséget, melyektől egyrészt az addikció, másrészt az addikt jellegü szervezeti viselkedés természetéröl, hátteréről, mozgatóiról nyerhetünk újabb ismereteket. Tanulmányomnak a Jel-Kép 2016/2 számában következő második részében az addikt kollektív ágens két szimptomatikus intézményének szakmai elemzésére kerítek sort. (A tanulmány első és második felének közös irodalomjegyzéke a második rész végén lesz található.)

${ }^{15}$ Kis ország, kis szakma, összefonódó kapcsolatrendszer, törékeny szakmai háttér mellett, pályázati, elosztási, bírálati, felhasználási rendszerek átfedése, kialakulatlan szakmai identitás, mindenkinek újszerü kihívások, lehetőségek. Bizonytalan kontroll mellett gyenge integritás, fokozott hagyományos „orvosi tekintély”, plusz „'́róasztal-tekintély”, stb teremtenek fellazult társadalmi kommunikatív feltételeket. A színtér integritásáról lásd Antal-Kiss (2012), Klotz-Sántha (2013).

${ }^{16}$ A korábban háttérbe szorított, lekezelt szakma gyors felépülésének és kitörésének ígérete.

${ }^{17}$ Kollektív integritás gyengesége, gyors előrejutás lehetősége. 